Jurnal Penelitian dan Pengabdian Kepada Masyarakat Bidang ilmu Pendidikan

\title{
Perbedaan Hasil Belajar Siswa yang Diajar Menggunakan Model Pembelajaran Soal Terbuka dengan Model Pembelajaran Konvensional
}

\author{
Asmedy \\ Program Studi Pendidikan Teknologi Informasi, STKIP Yapis Dompu \\ E-mail: asmedy.ntb@gmail.com
}

Article History: Received: 2021-01-05 || Revised: 2021-02-15 || Published: 2021-03-10

Sejarah Artikel : Diterima: 2021-01-05 || Direvisi: 2021-02-15 || Dipublikasi: 2021-03-10

\begin{abstract}
The open problem learning model as well as the conventional learning model is a learning model that is able to activate students in gaining knowledge and learning experience from accepted mathematical concepts. The purpose of this study was to determine the differences in student learning outcomes between those taught using open-ended learning models and conventional learning models. This research was conducted at SMP 4 Pancasila Donggo Bima in April. The research subjects were 70 students in two classes, namely class VIIIA and class VIIIB. This study used an experimental design, namely, one class of experimental learning using openended learning models and one control class learning using conventional learning models. The results obtained in this study are learning outcomes using open-ended learning models and conventional learning models. The T-test conducted showed a difference. The average learning outcomes of the experimental class students after treatment was 33.0625 while the learning outcomes of the control class were 39.4167. The conclusion that can be drawn from the results of data analysis and discussion is that there are differences in student learning outcomes between those taught using the open question learning model with conventional learning models, and the open question learning model is suitable to be applied to the subject of building space for students at SMP 4 Pancasila Donggo Bima Academic Year 2019/2020.
\end{abstract}

Keywords: Learning Outcomes, Open-ended, Conventional

\begin{abstract}
Abstrak
Model pembelajaran soal terbuka maupun model pembelajaran konvensional merupakan model pembelajaran yang mampu mengaktifkan siswa dalam memperoleh pengetahuan dan pengalaman belajar dari konsep matematika yang diterima. Tujuan dari penelitian ini adalah ingin mengetahui perbedaan hasil belajar siswa antara yang diajar dengan menggunakan model pembelajaran soal terbuka dan model pembelajaran konvensional. Penelitian ini dilakukan di SMP 4 Pancasila Donggo Bima pada bulan April. Subjek penelitian adalah 70 siswa di dua kelas yaitu kelas VIIIA dan kelas VIIIB. Penelitian ini menggunakan design eksperimental yaitu, satu kelas eksperimen belajar dengan menggunakan model pembelajaran soal terbuka dan satu kelas kontrol belajar dengan menggunakan model pembelajaran konvensional. Hasil yang diperoleh dalam penelitian adalah hasil belajar dengan menggunakan model pembelajaran soal terbuka dan model pembelajaran konvensional. Uji T-test yang dilakukan menunjukkan terdapat perbedaan. Rata-rata hasil belajar siswa kelas eksperimen setelah perlakuan adalah 33,0625 sedangkan hasil belajar kelas kontrol adalah 39,4167. Kesimpulan yang dapat diambil dari hasil analisis data dan pembahasan adalah terdapat perbedaan hasil belajar siswa antara yang diajar dengan menggunakan model pembelajaran soal terbuka dengan model pembelajaran konvensional, dan model pembelajaran soal terbuka cocok diterapkan pada pokok bahasan bangun ruang siswa SMP 4 Pancasila Donggo Bima Tahun Pelajaran 2019/2020.
\end{abstract}

Kata kunci: Learning Outcomes, Open-ended, Conventional

\section{PENDAHULUAN}

Pendidikan merupakan pendewasaan peserta didik agar dapat mengembangkan bakat, potensi dan keterampilan yang dimiliki dalam menjalani kehidupan. Selain itu pendidikan merupakan usaha sadar untuk mewujudkan suasana belajar dan proses pembelajaran agar peserta didik secara aktif mengembangkan potensi dalam dirinya, untuk mengembangkan potensi peserta didik tersebut maka dalam proses belajar dan pembelajaran, di samping penguasaan dalam materi 
pelajaran, siswa juga harus dibekali dengan kemampuan berpikir logis, kritis, dan kreatif, serta kemampuan bekerjasama. Kompetensi tersebut diperlukan agar peserta didik dapat memiliki kemampuan memperoleh, mengelola, dan memanfaatkan informasi untuk bertahan hidup pada keadaan yang selalu berubah, tidak pasti, dan kompetitif.

Usaha untuk mengembangkan potensi peserta didik serta untuk meningkatkan kualitas pendidikan, khususnya pendidikan matematika telah banyak dilakukan, bahkan terus menerus diupayakan, namun mutu pendidikan yang dicapai belum sesuai dengan harapan yang di inginkan. Berdasarkan hasil wawancara dengan beberapa guru yang sudah berpengalaman menjadi guru matematika, khususnya guru SMP 4 Pancasila Donggo Bima, bahwa dalam mempelajari matematika diharapkan siswa tidak hanya mengingat, memahami, dan menerapkan saja, akan tetapi siswa diharapkan juga dapat menganalisis dan mengevaluasi informasi. Karena itu, dalam pembelajaran matematika guru tidak mentransfer ilmu kepada siswa tetapi bagaimana guru mengarahkan siswa untuk membangun pengetahuan baru sesuai dengan pemikiran mereka sendiri. Soedjadi (2000:6) berpendapat bahwa "seorang guru akan mampu menggunakan matematika untuk membawa siswa menuju tujuan yang ditetapkan, bila siswa dapat memahami dengan baik matematika yang akan digunakan sebagai wahana pendidikan". Apabila pemahaman guru terhadap matematika kurang baik dapat dipastikan bahwa penggunaan matematika sebagai wahana pendidikan juga tidak akan berhasil seperti yang diharapkan.

Soejadi (2000:45), mengemukakan bahwa "pendidikan matematika seharusnya memperhatikan dua tujuan, yaitu (1) tujuan yang bersifat formal, dan (2) tujuan yang bersifat material”. Adapun tujuan yang berisfat formal lebih menekankan pada penataan nalar serta pembentukkan kepribadian, sedangkan tujuan yang bersifat material lebih menekankan pada penerapan matematika dan keterampilan matematika". Dari hal-hal tersebut di atas untuk mencapai tujuan pendidikan matematika peran guru sangat penting. Dengan perkembangan jaman banyak bermunculan model-model pembelajaran yang ada di sekolah-sekolah. Dari model pembelajaran konvensional, berkembang menjadi model pembelajaran yang menarik dan tidak membosankan lagi. Tetapi masih banyak guru atau tenaga pengajar yang memakai model pembelajaran konvensional dalam kegiatan pembelajaran. Ini bisa berarti bahwa guru atau tenaga pengajar hanya bisa memakai model pembelajaran konvensional dan tidak berusaha untuk mencari model-model pembelajaran yang mungkin lebih bagus dan lebih cocok diterapkan untuk siswa-siswanya, atau bisa jadi hanya model pembelajaran konvensional yang cocok diterapkan untuk siswa-siwanya.

Model pembelajaran konvensional yaitu model pembelajaran yang menekankan cara penyampaian pembelajaran dimana guru lebih aktif di depan dan siswa-siswanya hanya memperhatikan dan cenderung pasif. Pembelajaran pada model konvensional lebih berpusat pada guru sehingga tidak memberi kesempatan siswa untuk berpikir logis, kritis, dan kreatif, serta kemampuan bekerjasama. Model pembelajaran konvensional dapat dimaknai sebagai model pembelajaran yang lebih banyak berpusat pada guru, komunikasi lebih banyak satu arah dari guru ke siswa, metode pembelajaran lebih banyak menggunakan ceramah dan demonstrasi, dan materi pembelajaran lebih pada penguasaan konsep-konsep bukan kompetensi. Dalam proses belajar mengajar, perlu memberikan kesempatan pada siswa untuk berpikir dengan bebas sesuai dengan minat dan kemampuannya. Untuk itu penggunaan model pembelajaran sangatlah penting untuk keberhasilan suatu kegiatan belajar mengajar. Salah satu model pembelajaran yang dapat digunakan yaitu dengan model pembelajaran soal terbuka. Dengan model pembelajaran soal terbuka diharapkan aktivitas kelas akan penuh dengan ide-ide matematika dan pada akhirnya dapat meningkatkan kreativitas dan hasil belajar serta dapat mengembangkan potensi diri siswa. Tujuan dari model pembelajaran soal terbuka adalah bukan untuk mendapatkan jawaban tetapi lebih menekankan pada cara bagaimana sampai pada suatu jawaban. Dengan demikian tidak hanya 
terdapat satu pendekatan atau metode dalam mendapatkan jawaban yang benar, namun beberapa atau banyak sifat "keterbukaan".

Hudojo (1990:40) mengemukakan bahwa "matematika adalah suatu alat untuk mengembangkan cara berfikir". Hal tersebut berarti dengan model pembelajaran soal terbuka yang memberi kesempatan pada siswa dalam pemecahan masalah sesuai dengan kemampuan cara berfikirnya dalam proses belajar dan pembelajaran matematika lebih baik dari pada dengan model pembelajaran konvensional yang lebih menekankan kegiatan belajar berpusat pada guru, sehingga siswa lebih pasif dan siswa tidak dapat mengembangkan cara berfikirnya. Model pembelajaran soal terbuka memberikan kesempatan kepada siswa untuk memformulasikan berbagai strategi dan cara yang diyakininya sesuai dengan kemampuan mengkolaborasi permasalahan. Hal ini bertujuan agar kemampuan berpikir matematika siswa dapat berkembang secara maksimal dan merangsang kreativitas siswa, karena siswa diberikan permasalahan kemudian diberi keleluasaan dalam memberikan jawaban. Model pembelajaran yang dikembangkan oleh Khabibah memuat fase-fase kerja secara individual, diskusi kelompok, dan presentasi hasil belajar kelompok. Fase-fase model pembelajaran soal terbuka dapat dilihat pada Tabel berikut.

Tabel 1. Fase-fase Model Pembelajaran Matematika dengan Soal Terbuka

\begin{tabular}{|c|c|c|}
\hline Fase-fase & Aktivitas Guru & Aktivitas Siswa \\
\hline 1. Orientasi & $\begin{array}{l}\text { Guru memotivasi siswa dengan soal } \\
\text { yang berkaitan dengan kehidupan } \\
\text { sehari-hari siswa, juga menjelaskan } \\
\text { tujuan yang akan dicapai setelah } \\
\text { pembelajaran. }\end{array}$ & $\begin{array}{l}\text { Siswa mendengar penjelasan } \\
\text { guru, menjawab } r \text { atau } \\
\text { mengerjakan soal jika ada } \\
\text { pertanyaan atau soal yang } \\
\text { disampaikan oleh guru. }\end{array}$ \\
\hline $\begin{array}{l}\text { 2. Pembekalan } \\
\text { dan penyajian } \\
\text { soal terbuka }\end{array}$ & $\begin{array}{l}\text { Guru memberikan penjelasan umum } \\
\text { tentang materi yang akan dipelajari } \\
\text { siswa. Penjelasan umum ini } \\
\text { dimaksudkan agar siswa dalam } \\
\text { menyelesaikan soal yang bersifat } \\
\text { terbuka yang akan diselesaikan pada } \\
\text { fase berikutnya tidak dalam keadaan } \\
\text { "kosong". Apabila materi itu bukan } \\
\text { materi baru, artinya siswa sudah } \\
\text { mempunyai konsep-konsep dasar } \\
\text { matematika, pembekalan bisa berupa } \\
\text { permainan untuk membekali siswa } \\
\text { dalam menyelesaikan soal terbuka yang } \\
\text { akan diberikan. Guru menyampaikan } \\
\text { tugas-tugas atau soal yang harus } \\
\text { dikerjakan atau diselesaikan oleh siswa } \\
\text { baik secara individu maupun kelompok. }\end{array}$ & $\begin{array}{l}\text { Siswa mendengarkan penjelasan } \\
\text { guru dan mencatat soal yang } \\
\text { diberikan atau menerima } \\
\text { lembaran soal jika soal sudah } \\
\text { dalam bentuk lembaran. }\end{array}$ \\
\hline
\end{tabular}

\begin{tabular}{lll}
\hline 3. Pengerjaan & Guru mengambil hasil pekerjaan siswa & Siswa secara individu \\
soal terbuka & setelah habis waktu yang diberikan, & mengerjakan soal terbuka. Untuk \\
secara individu & & menyelesaikan soal, siswa \\
& & dibagikan lembar jawaban dan \\
& buram yang nantinya baik lembar \\
& jawaban maupun buram harus \\
dikumpulkan.
\end{tabular}

\begin{tabular}{llll}
\hline 4. Diskusi & Guru meminta siswa bergabung dengan & \multicolumn{2}{l}{ Siswa secara kelompok berdiskusi } \\
kelompok & kelompok untuk berdiskusi & untuk menyelesaikan tugas \\
tentang soal & menyelesaikan tugas kelompok. (soal & kelompok. \\
terbuka & yang didiskusikan dalam kelompok sama & \\
\hline
\end{tabular}




\begin{tabular}{|c|c|}
\hline & $\begin{array}{l}\text { dengan tugas individu pada fase } \\
\text { sebelumnya). }\end{array}$ \\
\hline $\begin{array}{l}\text { 5. Presentasi } \\
\text { hasil diskusi } \\
\text { kelompok }\end{array}$ & 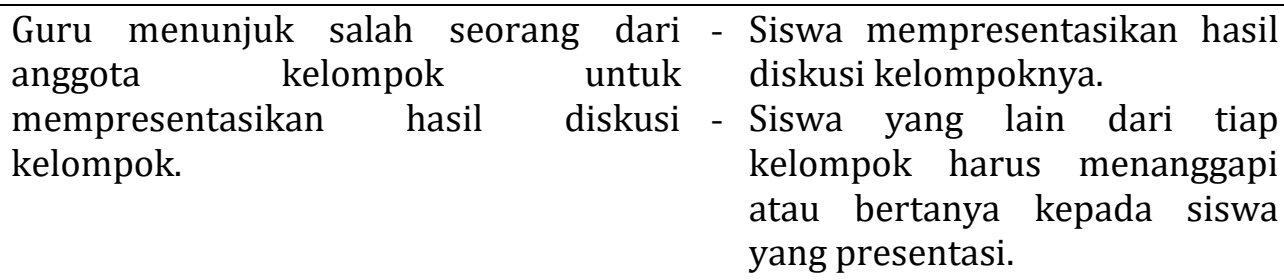 \\
\hline
\end{tabular}

6. Penutup

Guru bersama siswa menyimpulkan ide atau konsep yang telah diperoleh pada hari itu. Teknik yang digunakan seperti guru memberikan pertanyaanpertanyaan yang merangsang siswa untuk memperoleh poin-poin penting yang diharapkan.

Siswa mencatat kesimpulan yang diperoleh.

Dalam model pembelajaran soal terbuka terdapat beberapa keunggulan dan kelemahan. Menurut Takahashi (dalam Ali, 2008:4), keunggulan model pembelajaran soal terbuka adalah sebagai berikut :

1) Siswa menjadi lebih aktif dalam mengekspresikan ide-ide mereka.

2) Siswa mempunyai kesempatan lebih untuk secara komprehensif menggunakan pengetahuan dan keterampilan mereka.

3) Siswa mempunyai pengalaman yang kaya dalam proses menemukan dan menerima persetujuan dari siswa lain terhadap ide-ide mereka.

Kelemahan model pembelajaran soal terbuka adalah sebagai berikut:

1) Sukar bagi guru untuk menyajikan soal secara jelas.

2) Siswa yang berkemampuan tinggi mungkin mengalami kecemasan tentang jawabannya.

3) Mungkin ada sebagian siswa yang merasa kegiatan belajar mengajar mereka tidak menyenangkan karena kesulitan yang mereka hadapi.

Meskipun demikian, kelemahan yang dimiliki dalam model pembelajaran soal terbuka masih dapat diminimalkan. Adapun cara yang dapat dilakukan guru untuk mengatasi kelemahan dari model pembelajaran soal terbuka yaitu :

1) Membuat persiapan yang sebaik mungkin, sehingga masalah yang dibuat guru dapat bermakna dan dapat dengan mudah dipahami siswa.

2) Memberi tahu siswa bahwa soal (masalah) yang mereka terima adalah masalah soal terbuka yang memiliki banyak jawaban atau banyak cara penyelesaian.

3) Memberitahukan bahwa model pembelajaran soal terbuka lebih menekankan pada proses dari pada hasil yang didapatkan.

Menurut informasi dari seorang guru matematika SMP 4 Pancasila Donggo Bima yang sudah lama mengajar, masih banyak guru atau tenaga pengajar yang memakai model pembelajaran konvensional dalam kegiatan pembelajaran, sehingga siswa cenderung pasif pada saat kegiatan pembelajaran dan kerjasama antar siswa juga tidak terjalin dengan baik. Hal ini dapat dilihat dari hasil belajar yang dicapai siswa sering kali tidak sesuai dengan hasil belajar yang diinginkan oleh guru. Berdasarkan uraian di atas, perlu kiranya diteliti apakah pengajaran dengan model pembelajaran soal terbuka lebih baik dari pada model pembelajaran konvensional. Karena itu peneliti tertarik untuk melakukan penelitian tentang "Perbedaan Hasil Belajar Matematika Siswa Dengan Menggunakan Model Pembelajaran Soal Terbuka Dan Model Pembelajaran Konvensional 
Pada Pokok Bahasan Bangun Ruang di Kelas VIII SMP 4 Pancasila Donggo Bima Tahun Pembelajaran 2019/2020".

\section{METODE PENELITIAN}

Penelitian ini termasuk jenis penelitian eksperimental. "Dalam penelitian eksperimen ada perlakuan (treatment), sedangkan dalam penelitian naturalistik tidak ada perlakuan. Dengan demikian metode penelitian eksperimen dapat diartikan sebagai metode penelitian yang digunakan untuk mencari pengaruh perlakuan tertentu terhadap yang lain dalam kondisi yang dikendalikan" (Sugiyono, 2010:107). Jadi dalam penelitian eksperimental terdapat perbedaan antara penelitian yang mendapatkan perlakuan dengan yang tidak mendapatkan perlakuan. Dalam penelitian eksperimental terdapat dua variabel yaitu bebas atau perlakuan dan variabel kontrol. Variabel bebas atau perlakuan dalam penelitian ini adalah pembelajaran dengan menggunakan model pembelajaran soal tebuka, sedangkan variabel kontrol dalam penelitian ini adalah pembelajaran dengan menggunakan model pembelajaran konvensional, Adapun prosedur dalam penelitian ini adalah sebagai berikut:

1) Persiapan, dengan mempersiapkan yang diperlukan untuk kegiatan-kegiatan penelitian seperti surat permohonan izin penelitian, konsultasi materi, dan jadwal mengajar.

2) Menentukan populasi dan daerah penelitian dengan teknik sampling purposive yaitu siswa kelas VIII SMP 4 Pancasila Donggo Bima.

3) Mencari kelas yang mempunyai tingkat kemampuan yang sama dalam hal prestasi dan lain-lain, untuk dijadikan tempat penelitian. Dan mengadakan uji homogenitas terhadap nilai ulangan harian matematika pada pokok bahasan sebelumnya untuk mengetahui kelas yang mempunyai tingkat varians data yang sama atau tidak, dengan uji homogenitas.

4) Menentukan sampel dengan teknik cluster sampling sebanyak 2 kelas.

5) Selanjutnya melakukan teknik undian untuk menentukan kelas eksperimen yang menerima pembelajaran soal terbuka dan kelas kontrol yang menerima pembelajaran dengan model pembelajaran konvensional.

6) Melakukan pre-test terhadap kelas eksperimen dan kelas control sebelum dilakukan proses belajar mengajar untuk mengetahui kamampuan awal siswa.

7) Mengadakan perlakuan terhadap subyek penelitian yaitu melaksanakan pembelajaran di kelas eksperimen dengan menggunakan model pembelajaran soal terbuka dan melaksanakan pembelajaran di kelas kontrol dengan model pembelajaran konvensional.

8) Melakukan post-test terhadap kelas eksperimen dan kelas kontrol.

9) Mendapatkan hasil dari melakukan post-test

10) Analisis data dengan uji hipotesis nilai tes hasil belajar siswa kelas eksperimen dan kontrol.

11) Uji hipotesis, untuk menentukan perbedaan hasil belajar kelas eksperimen dan kelas kontrol.

12) Kemudian di uji lagi homogenitasnya apakah kelas tetap homogen.

13) Memberikan kesimpulan dari hasil analisis data.

Secara garis besar dapat dilukiskan pada bagan arus penelitian yang akan dilakukan adalah sebagai berikut: 


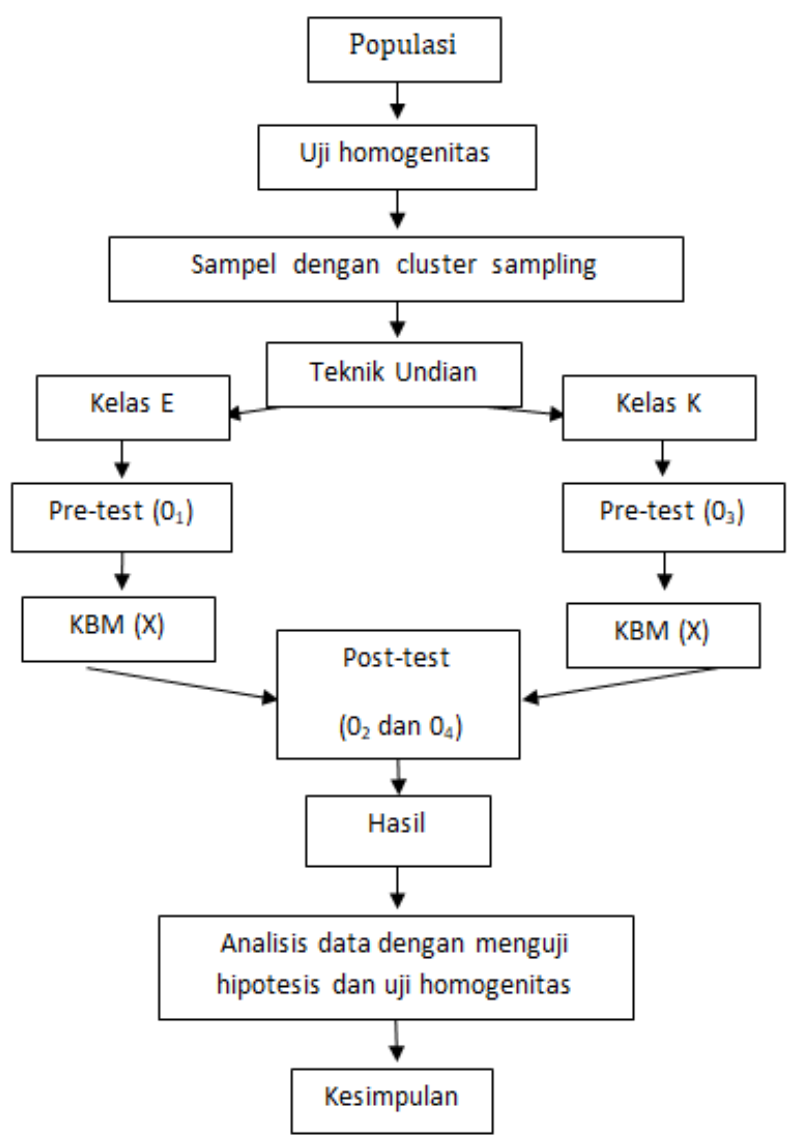

Gambar 1. Bagan Arus Penelitian

\section{HASIL DAN PEMBAHASAN}

Data yang diperoleh dalam penelitian ini merupakan data hasil tes siswa baik pre-test maupun pos-test antara kedua kelas yaitu kelas eksperimen (kelas yang diajar dengan menggunakan model pembelajaran soal terbuka) dan kelas kontrol (kelas yang diajar dengan menggunakan model pembelajaran konvensional).

\section{1) Pelaksanaan Penelitian}

Penelitian ini dilaksanakan di SMP 4 Pancasila Donggo Bima. Penelitian dilaksanakan pada tanggal 03 April 2020 - 19 April 2020. Kegiatan awal penelitian dimulai dengan memberikan pre-test pada kelas eksperimen dan kelas kontrol, kemudian pertemuan selanjutnya yaitu pemberian materi, dimana peneliti mengajar dengan menggunakan model pembelajaran soal terbuka pada kelas eksperimen dan mengajar dengan menggunakan model pembelajaran konvensional pada kelas kontrol. Pemberian materi dilakukan sebanyak empat kali, tiap materi diberi waktu 2 jam pelajaran 2 x 40 menit. Dan pertemuan terakhir berupa pemberian post-test pada kelas eksperimen dan kelas kontrol.

\section{2) Hasil Pre-Test}

Sebelum siswa mendapatkan perlakuan dilakukan uji homogenitas terlebih dahulu dengan data yang digunakan adalah hasil pre-test. Pre-test untuk kelas eksperimen dan kelas kontrol dilakukan pada tanggal 03 April 2020. Soal yang digunakan pada pre-test nantinya juga digunakan untuk post-test, soal yang di teskan sebanyak lima butir berbentuk uraian, dapat dilihat pada lampiran 24. Dari soal tersebut kemudian diperoleh nilai hasil pre-test, dapat dilihat pada lampiran 31. Adapun nilai yang terendah pada kelas kontrol adalah 5 dan nilai 
tertingginya adalah 55 kemudian untuk kelas eksperimen nilai terendah adalah 10 dan nilai tertingginya adalah 51.

Tabel 2. Nilai hasil pre-test siswa kelas eksperimen dan control

\begin{tabular}{clcc}
\hline No & Komponen & Kelas Eksperimen VIII A & Kelas Kontrol VIII B \\
\hline 1 & Jumlah Siswa & 35 & 35 \\
\hline 2 & Nilai Terendah & 10 & 5 \\
\hline 3 & Nilai Tertinggi & 51 & 55 \\
\hline 4 & Nilai Rata-Rata & 30,629 & 28,714 \\
\hline 5 & Varians & 108,887 & 199,445 \\
\hline 6 & Simpangan Baku & 10,435 & 14,123 \\
\hline
\end{tabular}

\section{3) Hasil Post-Test}

Post-test untuk kelas eksperimen dilakukan pada hari Kamis tanggal 18 April 2020 dan untuk kelas kontrol dilakukan pada hari Jum'at tanggal 19 April 2020. Soal post-tes yang akan di teskan sebanyak lima butir dimana berbentuk uraian, dapat dilihat pada lampiran 24. Dari soal tersebut kemudian diperoleh hasil belajar siswa, nilai hasil post-test dapat dilihat pada lampiran 31. Adapun nilai yang terendah pada kelas kontrol adalah 23 dan nilai tertingginya adalah 100 kemudian untuk kelas eksperimen nilai terendah adalah 40 dan nilai tertingginya adalah 100 . Untuk lebih jelasnya dapat dilihat pada tabel berikut:

Tabel 3. Perbandingan nilai hasil post-test siswa kelas eksperimen dan kontrol

\begin{tabular}{clcc}
\hline NO & Komponen & Kelas Eksperimen VIII A & Kelas Kontrol VIII B \\
\hline 1 & Jumlah Siswa & 35 & 35 \\
\hline 2 & Nilai Terendah & 40 & 23 \\
\hline 3 & Nilai Tertinggi & 100 & 100 \\
\hline 4 & Nilai Rata-Rata & 69,657 & 56,886 \\
\hline 5 & Varians & 631,879 & 413,398 \\
\hline 6 & Simpangan Baku & 25,137 & 20,332 \\
\hline
\end{tabular}

\section{4) Hasil Analisis Data}

Dalam analisis pendahuluan dicari normalitas dan homogenitas kelas baik kelas eksperimen maupun kelas kontrolnya. Dibandingkan antara kedua kelas apakah kelas homogen dan berdistribusi normal atau tidak. Semua data baik hasil pre-test maupun post-test diuji normalitasnya dan homogenitasnya.

\section{a. Uji Normalitas}

Zainal Arifin (2011:287) mengatakan "jumlah data di atas 30, sehingga tidak perlu dilakukan uji normalitas data". Maka dalam penelitian ini peneliti tidak menggunakan uji normalitas karena banyaknya siswa di kelas eksperimen dan kelas kontrol lebih dari 30 siswa.

\section{b. Uji Homogenitas}

Uji Homogenitas untuk mengetahui variansinya homogen atau tidak dilakukan menggunakan rumus varian terbesar banding varian terkecil pada nilai pre-tes maupun pada nilai post-test. Kelas dikatakan variansinya homogen jika $\mathrm{F}_{\text {hitung }}<\mathrm{F}_{\text {tabel. }}$. Selanjutnya di uji menggunakan uji t-test jika $\mathrm{t}_{\text {hitung }}<\mathrm{t}$ tabel dengan demikian dapat dinyatakan pada kelas eksperimen dan kelas kontrol tidak terdapat perbedaan (homogen). 
a. Adapun kaidah keputusan yang berlaku:

Sepasang kelas homogen jika $t_{\text {hitung }}<t_{\text {tabel }}$

Sepasang kelas tidak homogen jika $\mathrm{t}_{\text {hitung }}>\mathrm{t}_{\text {table }}$

b. Tabel uji homogenitas hasil pre-tes dan post-test adalah sebagai berikut:

Tabel 4. Uji Homogenitas Pre-test Kelas eksperimen dan kelas control

\begin{tabular}{|c|c|c|c|c|c|c|c|c|c|}
\hline No & Kelas & $\mathbf{N}$ & $\begin{array}{l}\text { Rata- } \\
\text { Rata }\end{array}$ & $\begin{array}{l}\text { Standar } \\
\text { Deviasi }\end{array}$ & Varian & $\mathbf{F}_{\text {hitung }}$ & $\mathbf{F}_{\text {tabel }}$ & $\mathbf{t}_{\text {hitung }}$ & $t_{\text {tabel }}$ \\
\hline 1 & VIII A & 35 & 30,629 & 10,435 & 108,887 & \multirow{2}{*}{1.832} & \multirow{2}{*}{1.776} & \multirow{2}{*}{0,645} & \multirow{2}{*}{1,999} \\
\hline 2 & VIII B & 35 & 28,714 & 14,123 & 199,445 & & & & \\
\hline
\end{tabular}

Tabel 5. Uji Homogenitas Post-test Kelas eksperimen dan kelas kontrol

\begin{tabular}{cccccccccc}
\hline No & Kelas & $\mathbf{N}$ & $\begin{array}{c}\text { Rata- } \\
\text { Rata }\end{array}$ & $\begin{array}{c}\text { Standar } \\
\text { Deviasi }\end{array}$ & Varian & $\mathbf{F}_{\text {hitung }}$ & $\mathbf{F}_{\text {tabel }}$ & $\mathbf{t}_{\text {hitung }}$ & $\mathbf{t}_{\text {tabel }}$ \\
\hline 1 & VIII A & 35 & 69,637 & 25,137 & 631,879 & \multirow{2}{*}{1.529} & 1.776 & 2,337 & 1.999 \\
\hline 2 & VIII B & 35 & 56,886 & 20,332 & 413,398 & & & & \\
\hline
\end{tabular}

Berdasarkan keterangan pada tabel uji homogenitas nilai post-test kelas eksperimen dan kelas kontrol yang disesuaikan dengan kaidah keputusan yang berlaku maka diperoleh kesimpulan bahwa kelas eksperimen dan kelas kontrol tidak homogen.

\section{c. Uji Hipotesis Penelitian}

Setelah dilakukan uji analisis pendahuluan selanjutkan dilakukan uji analisis untuk menjawab hipotesis. Adapun data yang akan diuji adalah data hasil post-test, data tersebut akan diuji dengan menggunkana uji t-tes. Adapun kriteria hipotesis yang digunakan untuk menjawab hipotesis yang diajukan adalah sebagai berikut jika $t_{\text {hitung }} \leq t$ tabel maka Ho diterima dan jika $t_{\text {hitung }} \geq t_{\text {tabel }}$ maka Ho ditolak dan taraf signifikasi tabel yang digunakan adalah $5 \%$. Adapun bunyi hipotesis yang akan dianalisi adalah sebagai berikut:

$\mathrm{H}_{0}$ : Tidak terdapat perbedaan hasil belajar matematika dengan menggunakan model pembelajaran soal terbuka dan model pembelajaran konvensional pada pokok bahasan bangun ruang di kelas VIII SMP 4 Pancasila Donggo Bima tahun pembelajaran $2019 / 2020$.

$\mathrm{H}_{1}$ : Terdapat perbedaan hasil belajar matematika dengan menggunakan model pembelajaran soal terbuka dan model pembelajaran konvensional pada pokok bahasan bangun ruang di kelas VIII SMP 4 Pancasila Donggo Bima tahun pembelajaran 2019/2020.

Berdasarkan hasil perhitungan diperoleh nilai $t_{\text {hitung }}$ adalah 2,337 dan $t_{\text {tabel }}$ adalah 1.999 untuk taraf signifikansi 5\%. Jika disesuaikan dengan hipotesis berdasarkan kriteria pengujian, Ho diterima jika $t_{\text {hitung }}<t_{\text {tabel }}$. Maka dapat dilihat bahwa $t_{\text {hitung }}>t_{\text {tabel }}$ dengan taraf signifikansi 5\% sehingga dapat ditarik kesimpulan bahwa Ho ditolak dan Ha diterima. Hipotesisnya berbunyi "Terdapat perbedaan hasil belajar matematika dengan menggunakan model pembelajaran soal terbuka dan model pembelajaran konvensional pada pokok bahasan bangun ruang di kelas VIII SMP 4 Pancasila Donggo Bima tahun pembelajaran 2019/2020". 


\section{SIMPULAN DAN SARAN}

A. Simpulan

Berdasarkan hasil penelitian, analisis data, pengujian hipotesis dan pembahasan diperoleh bahwa penelitian berhasil dan dapat disimpulkan sebagai berikut:

1. Terdapat perbedaan hasil belajar matematika dengan menggunakan model pembelajaran soal terbuka dan model pembelajaran konvensional pada pokok bahasan bangun ruang di kelas VIII SMP 4 Pancasila Donggo Bima tahun pembelajaran 2019/2020.

2. Pembelajaran model soal terbuka cocok diterapkan pada pokok bahasan bangun ruang di kelas VIII SMP 4 Pancasila Donggo Bima tahun pembelajaran 2019/2020.

\section{B. Saran}

Beberapa saran yang dapat penulis berikan yaitu:

1. Penggunaan model pembelajaran soal terbuka juga bisa dikembangkan untuk mata pelajaran lain sehingga dapat meningkatkan hasil belajar serta kemampuan berpikir kreatif siswa

2. Bagi peneliti lain yang ingin meneliti menggunakan model pembelajaran soal terbuka diharapkan benar-benar menguasai tahapan pembelajarannya dan dapat menggunakan waktu seefektif dan seefisien mungkin.

\section{DAFTAR RUJUKAN}

Arifin, Z. 2011. Penelitian Pendidikan Metode dan Paradigma Baru. Bandung: ROSDA.

Arikunto, S. 1998. Prosedur Penelitian Suatu Pendekatan Praktek (Edisi Revisi IV). Jakarta: PT Rineka Cipta.

Asmedy. 2012. Pengembangan Perangkat Pembelajaran Logika Dengan Pendekatan Open Ended Di Kelas X Sekolah Menengah Atas. Disertasi tidak diterbitkan. Surabaya: Program Pascasarjana UNESA.

Asmedy. (2018). Pengembangan Perangkat Pembelajaran Bangun Datar dengan Pendekatan Open Ended. JIIP - Jurnal Ilmiah Ilmu Pendidikan, 1(2), 66-72. Retrieved from http://iiip.stkipyapisdompu.ac.id/jiip/index.php/IIIP/article/view/11

Asmedy. (2020). Perbandingan Hasil Belajar Connected Mathematics Project (CMP) dengan Pembelajaran Konvensional Pada Pokok Bahasan Geometri. JIIP - Jurnal Ilmiah Ilmu Pendidikan, 3(1), 456-464. Retrieved from http://jiip.stkipyapisdompu.ac.id/jiip/index.php/JIIP/article/view/131

Badan Standar Nasional Pendidikan. 2006. KTSP Dan Penilaian Pembelajaran Matematika Berbasis Kompetensi. Jakarta: BSNP.

Basleman, A. \& Mappa, S. 2011. Teori Belajar Orang Dewasa. Bandung: PT Remaja Rosdakarya.

Fathirma'ruf, F., \& Said, M. B.(2020). Pengembangan Perangkat Pembelajaran Konstruktivistik Model Teaching with Analogies (TWA) pada Mata Kuliah Database Management System (DBMS) untuk Meningkatkan Kemampuan Berpikir Kreatif Mahasiwa. Jurnal Teknologi Informasi dan Ilmu Komputer, 7(5), 1051-1060.

Fathirma'ruf, Budiman, \& Asmedy. (2019). Analisis Validitas dan Reliabilitas Keterbacaan Buku Ajar perkuliahan Berbasis Analogi. JIIP - Jurnal Ilmiah Ilmu Pendidikan, 2(3), 336-340. Retrieved from http://jiip.stkipyapisdompu.ac.id/jiip/index.php/IIIP/article/view/67

Hudojo, H. 1990. Pengembangan Kurikulum Dan Pembelajaran Matematika. Malang: Universitas Negeri Malang.

Jihad \& Haris. 2010. Evaluasi Pembelajaran. Yogyakarta: Multi Pressindo. 
Riduwan. 2010. Belajar Mudah Penelitian Untuk Guru-Karyawan Dan Peneliti Pemula. Bandung: ALFABETA.

Ruseffendi. 1998. Dasar-Dasar Penelitian Pendidikan Dan Bidang Non-Eksakta Lainnya. Semarang: IKIP Semarang.

Soedjadi, R. 2000. Kiat Pendidikan Matematika Di Indonesia. Jakarta: Departemen Pendidikan Nasional.

Sudjana. 2005. Metoda Statistika. Bandung: TARSITO.

Sugiyono. 2007. Statistika Untuk Penelitian. Bandung: ALFABETA.

Sugiyono. 2010. Metode Penelitian Pendidikan. Bandung: ALFABETA.

Tampomas, H. 2005. Matematika 3 Untuk SMP/MTs Kelas IX. Jakarta: Yudhistira. 